\title{
Behavioral Comparison of Bali and Bali crossed Angus Cattle During Road-trip and Oversea Transportation
}

\author{
Bramada Putra ${ }^{1}$, Cuk Noviandi ${ }^{1}$, Rusman Rusman ${ }^{1}$, Tri Widi ${ }^{1}$ and Endang Baliarti ${ }^{1, *}$ \\ ${ }^{1}$ Faculty of Animal Science, Universitas Gadjah Mada, Yogyakarta 55281 Indonesia \\ *Corresponding author.Email: bali_arti@ugm.ac.id
}

\begin{abstract}
Transportation could lead to stress on livestock, and it can be assessed by measuring behavioral. The aims of this research were to examine the behavioral of Bali and Bali crossed Angus during road-trip and oversea transportation. The research used 5 Bali and 5 Bali crossed Angus cattle bulls with an average age of $\mathrm{I}_{0}-\mathrm{I}_{3}$ and the body weights for Bali and Bali crossed Angus were 214,7 $\pm 24,9 \mathrm{~kg}$ and $301,6 \pm 67,7 \mathrm{~kg}$ respectively. The transportation device was open deck truck with deck dimension was $8,04 \mathrm{~m}$ for length and 2,45 $\mathrm{m}$ for width that filled with 10 heads of cattle with random position between Bali and Bali crossed Angus cattle. Space allowance for each cattle was 1,97 $\mathrm{m}^{2}$. Oversea transportation observed during across of Sunda strait. Road trip transportation observed from Merak port to IPB Darmaga campus. Both of them take time \pm 3 hours. The cattle behavioral observed using Closed Circuit Television (CCTV) 1080P of resolution. Observation was made every 3 hour for 10 minutes $(600 \mathrm{sec})$. The parameters of behavior during transport observed comprised standing, lying, aggressiveness and ingestive (\% time observation). Data was analyzed by t-student test method. During road-trip transportation, Bali cattle had significantly behavior on aggressiveness $(5,31 \%)$ and ingestive $(1,61 \%)$ than Bali crossed Angus cattle $(3.11 \%)$ and $(4,81 \%)$. During oversea transportation Bali crossed Angus cattle had significantly behavior on standing (24\%) and lying (76\%) than Bali cattle (100\% lying). Bali cattle more active than Bali crossed Angus cattle on road-trip transportation but less on oversea transportation.
\end{abstract}

Keywords: Bali cattle, Bali crossed Angus cattle, behavioral, road-trip, oversea, transportation,

\section{INTRODUCTION}

The geographical condition of Indonesia, which is an archipelagic country, makes the process of livestock transportation both by land and sea are very important factor. The difference in the location of the beef production centers and consumption centers that are relatively far away requires an efficient transportation system to produce competitive products. Livestock transportation is an important component of the livestock industry [1]. The long-distance transportation of livestock has a huge impact on their welfare. During this transportation process, livestock are exposed to a new environment that is different from the previous environment so that they have the potential to experience stress. Stress in livestock can endanger animal welfare and health, reduce meat quality, and even cause death [2]. Various indicators of stress can be used to assess the effects of transport on animal welfare including anatomic changes, physiological responses, and behavioral changes [3]. This study is expected to provide information about changes in behavior of Bali and Bali crossed Angus cattle during long-distance transportation. Bali crossed Angus cattle are expected to have very good production and reproduction capabilities of Angus lineage cattle in Indonesia so that they can be used for beef-producing cattle breeding programs. Angus cattle which have a more docile temperament are expected to reduce stress levels during transportation.

\section{MATERIAL AND METHODS}

\subsection{Material}

The materials used were 5 Bali Cattle and 5 Angus Bali Cross Cattle, male with ages I0 to I3. The average weight of Bali cattle was $214.7 \pm 24.9 \mathrm{~kg}$ and Bali crossed Angus were $301.6 \pm 67.7 \mathrm{~kg}$. The feed used during the maintenance and reconditioning process is forage and concentrate. The equipment that will be used in the 
research is Closed Circuit Television (CCTV) with $1080 \mathrm{P}$ resolution. The mode of transportation is a Hino FG 235 Ti truck. The truck deck is $8.04 \mathrm{~m}$ long and 2.45 $\mathrm{m}$ wide. The truck is filled with 10 cows with random positions between Bali Cattle and Bali crossed Angus tied by a 1.5 to $2 \mathrm{~m}$ long rope. The space allowance for transportation is $1.97 \mathrm{~m} 2$ per cow. The floor and walls of the truck are made of iron, during the journey the floor is coated with sawdust.

\subsection{Method}

\subsubsection{General}

Observations of livestock behavior were carried out using 3 CCTV devices during transportation. Livestock transportation on roadtrip using truck mode of transportation and by sea using ferry ship. Observations of oversea transportation were carried out during the Sunda crossing from Bakauheni Port. South Lampung, Lampung to Merak Port, Cilegon, Banten. Observations of road trips were carried out while traveling from Merak Port, Cilegon, Banten to the stables of the Faculty of Animal Husbandry IPB, Darmaga, Bogor, West Java. The length of time for oversea and road trips is 3 hours each. The parameters of behavior during transport observed comprised standing, lying, aggressiveness and ingestive (\% time observation). physiology data recorded are respiration rate and heartbeat rate (times per minute). Physiology data was recorded at early hours and final hours of transportation.

\subsubsection{Statistic}

Behavioral data during land and sea trips were processed using student $t$ hypothesis testing to compare
Bali and Angus crossbreeds with Bali cattle. The model used to analyze was:

$$
t=\frac{\left(\bar{x}_{a}-\bar{x}_{b}\right)-\left(\bar{\mu}_{a}-\bar{\mu}_{b}\right)}{\sqrt{\frac{s_{a}^{2}}{n_{a}}+\frac{s_{b}^{2}}{n_{b}}}}
$$

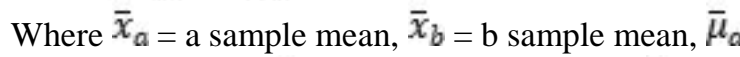
= a population mean, $\bar{\mu}_{b}=\mathrm{b}$ population mean, $s_{a}=\mathrm{a}$ standard deviation, $s_{b}=\mathrm{b}$ standard deviation, $n_{a}=\mathrm{a}$ sample amount, $n_{b}=\mathrm{b}$ sample amount. Significance was declared at $\mathrm{P}<0.05$.

\section{RESULT AND DISCUSSION}

Physiological responses and behavior of Bali and Bali crossed Angus cattle during oversea transportation are presented in Table 1 and Table 2. While the physiological responses and behavior of Bali and Bali crossed Angus cattle during road-trip transportation are presented in Table 3 and Table 4. Physiological response data explained that there was no significant difference in Bali and Bali crossed Angus cattle in oversea transportation and road-trip transportation. But it shows an increase in respiration rate and heartbeat rate in the first hour an then decreases in the last hour of transportation, especially in oversea transportation. This shows that the cattle are more sensitive to over sea transportation conditions than road-trip transportation.

Table 1. Cattle physiology during oversea transportation

\begin{tabular}{|l|l|l|}
\hline Variables & Bali & Bali Crossed Angus \\
\hline Respiration rate (early) & $18.60 \pm 1.34$ & $18.00 \pm 3.00$ \\
\hline Respiration rate (final) & $15.60 \pm 1.34$ & $16.20 \pm 1.64$ \\
\hline Heartbeat rate (early) & $86.40 \pm 15.13$ & $79.20 \pm+14.53$ \\
\hline Heartbeat rate (final) & $64.00 \pm 6.32$ & $62.40 \pm 3.58$ \\
\hline
\end{tabular}

Table 2. Cattle behavior during oversea transportation

\begin{tabular}{|l|l|l|}
\hline Variables & Bali & Bali Crossed Angus \\
\hline Standing (\%) & $00.00 \pm 0.00^{\mathrm{a}}$ & $24.00 \pm 2.24^{\mathrm{b}}$ \\
\hline Lying (\%) & $100.00 \pm 0.00^{\mathrm{a}}$ & $76.00 \pm 2.24^{\mathrm{b}}$ \\
\hline Aggressiveness (\%) & $00.00 \pm 0.00$ & $0.10 \pm 0.14$ \\
\hline Ingestive (\%) & $00.00 \pm 0.00$ & $0.79 \pm 1.35$ \\
\hline
\end{tabular}

Different superscript in the same row means significantly different $(\mathrm{P}<0.05)$ 
Table 3. Cattle physiology during roadtrip transportation

\begin{tabular}{|l|l|l|}
\hline Variables & Bali & Bali Crossed Angus \\
\hline Respiration rate (early) & $18.00 \pm 3.67$ & $17.40 \pm 3.29$ \\
\hline Respiration rate (final) & $19.20 \pm 1.64$ & $21.00 \pm 3.00$ \\
\hline Heartbeat rate (early) & $59.20 \pm 5.22$ & $60.80 \pm 11.80$ \\
\hline Heartbeat rate (final) & $56.80 \pm 3.35$ & $50.00 \pm 18.44$ \\
\hline
\end{tabular}

Table 4. Cattle behavior during roadtrip transportation

\begin{tabular}{|l|l|l|}
\hline 9 Variables & Bali & Bali Crossed Angus \\
\hline Standing (\%) & $83.25 \pm 18.41$ & $89.05 \pm 7.28$ \\
\hline Lying (\%) & $16.75 \pm 18.41$ & $10.95+7.28$ \\
\hline Aggressiveness (\%) & $5.31+3.20^{\mathrm{b}}$ & $3.11+2.01^{\mathrm{a}}$ \\
\hline Ingestive (\%) & $1.61+1.43^{\mathrm{a}}$ & $4.81+4.20^{\mathrm{b}}$ \\
\hline
\end{tabular}

Different superscript in the same row means significantly different $(\mathrm{P}<0.05)$

The existence of shocks due to sea waves during oversea transportation give more physiological impact than shocks during road-trip transportation. All Bali cattle are lying and not doing any activities including ingestive activities during oversea transportation. While in Bali crossed Angus cattle, there was a significant 24\% observation time to stand, with ingestive activity and aggressiveness although not significant. During road-trip transportation, both Bali and Bali crossed Angus cattle most of the time of the journey in a standing position. during the road-trip transportation Bali cattle were significantly more aggressive $(5.31 \%)$ than Bali crossed Angus cattle (3.11\%) but Bali crossed Angus cattle were more significant in ingestive activity $(4.81 \%)$ than Bali cattle $(1.61 \%)$.

\section{AUTHORS' CONTRIBUTIONS}

Oversea transportation gives greater physiological impact than road-trip transportation. Bali crossed Angus cattle have a more stable physiological response and behavior during transportation, both oversea and roadtrip transportation. this condition will provide a small risk for weight loss during transportation.

\section{ACKNOWLEDGMENTS}

This study was supported by a research grant for "Rekognisi Tugas Akhir" from Universitas Gadjah Mada.

\section{REFERENCES}

[1] Martin P, Bateson P. 1993. Measuring Behavior:an Introductury Guide. Massachussetts : Cambrige University Press.
[2] Fisher AD, Colditz IG, Drewe CL, Ferguson DM. (2009) The influence of land transport on animal welfare in extensive farming systems. Veterinary Behavior 4(4):157-162. https://doi.org/10.1016/j.jveb.2009.03.002.

[3] Haley DB, Rushen J, Passillé AM. 2000. Behavioural indicators of cow comfort: activity and resting behaviour of dairy cows in two types of housing. Animal Science 80(2): $257-$ 263. https://doi.org/10.4141/A99-084. 